\title{
STUDI MORFOLOGI, ONTOGENI, DAN STRATEGI REPRODUKSI PADA Melanoides tuberculata (MÜLLER, 1774) dan Stenomelania punctata (LAMARCK, 1822) (GASTROPODA: CERITHIOIDEA: THIARIDAE)
}

[Morphology, Ontogeny Studies and Reproduction Strategy of Melanoides tuberculata (Müller, 1774) dan Stenomelania punctata (Lamarck, 1822) from Indonesia (Gastropoda: Cerithioidea: Thiaridae)]

\section{Nur Rohmatin Isnaningsih ${ }^{*}$, Ristiyanti M. Marwoto*, Alfiah, Riena Prihandini, dan Pramono H. Santoso}

Museum Zoologicum Bogoriense, Pusat Penelitian Biologi-Lembaga Ilmu Pengetahuan Indonesia email : nr.isnaningsih@gmail.com

\section{ABSTRAK}

Keong air tawar Melanoides tuberculata (Thiaridae) memiliki distribusi global yang luas. Spesies ini mempunyai variasi yang tinggi pada karakter warna, ukuran dan motif cangkang. Bila dibandingkan dengan anggota Thiaridae yang lain yakni Stenomelania punctata, kedua nya memiliki ciri yang sama dalam bentuk cangkang memanjang, warna cangkang kehitaman, jumlah seluk dan ukuran cangkang. Riset ini bertujuan untuk membandingan dengan lebih detail antara M. tuberculata dengan S. punctata berdasarkan ciri morfologi, ontogeni dan tipe reproduksinya. Studi ontogeni pada kedua spesies tersebut menunjukkan bahwa M. tuberculata dalam reproduksinya menghasilkan juvenil berupa embryonic shell. Embryonic shell disimpan dan mengalami perkembangan dalam organ subhaemocoelic brood pouch induknya, terbukti dengan dijumpai ukuran yang bervariasi $(0,12-5,95 \mathrm{~mm})$. Tiap satu induk $M$. tuberculata mampu menghasilkan 1-66 embryonic shell. Adapun pada subhaemocoelic brood pouch S. punctata hanya terlihat adanya bentukan unshell embrio dan tidak dijumpai adanya embryonic shell. Perbedaan cara reproduksi itu menentukan strategi reproduksi pada kedua spesies tersebut. M. tuberculata bereproduksi secara euvivipar sedangkan S. punctata memiliki strategi reproduksi ovovivipar yang melepaskan juvenil dalam bentuk veliger yang berenang bebas.

Kata kunci : Melanoides tuberculata, Stenomelania punctata, karakter morfologi, strategi reproduksi, ontogeni.

\section{ABSTRACT}

The freshwater Melanoides tuberculata (Thiarid) has wide distribution and have many variation in color, size, and scluptured of their shells. Comparing with another Thiarid so called Stenomelania punctata, shell of M. tuberculata similar in having turreted shape, blackish color, number of whorls, and size of the shells. This study aim to compare more detailed between M. tuberculata and S. punctata based on their morphology, ontogeny and type of reproduction. Ontogeny studies of these two species show that M. tuberculata produces juveniles in embryonic shell form during their reproduction. This embryonic shell is nourished and developed in the subhaemocoelic brood-pouch organ as evidenced by being found in the size range $0.12-5.95 \mathrm{~mm}$. One individu M. tuberculata can produce 1-66 embryonic shells. Meanwhile, in subhaemocoelic brood-pouch of S. punctata only the unshell embryo was seen and embryonic shell was not found. The difference of reproduction system determines the reproductive strategy in both species. M. tuberculata conduct euviviparity reproduction whereas $S$. punctata is ovoviviparous that releases juveniles in free-swimming veliger form.

Keyworlds : Melanoides tuberculata, Stenomelania punctata, morphological characters, reproductive strategy, ontogeny.

\section{PENDAHULUAN}

Keong air tawar Genus Melanoides Olivier, 1804 merupakan jenis malakofauna umum yang banyak dijumpai hidup di sungai-sungai, sawah serta danau. Masyarakat lokal di Indonesia menyebutnya Sumpil (Jawa) atau Susuh (Sunda). Kelompok keong ini memiliki cangkang berukuran 18-40 mm dengan sulur yang panjang dan ujung yang runcing. Pada habitat hidupnya, Melanoides seringkali terlihat menempel pada batuan di dasar perairan dan tanaman air atau pada substrat tepian sungai (Djajasasmita, 1999).
Genus Melanoides membawahi sedikitnya 41 spesies dengan distribusi asal meliputi wilayah Afrika dan Asia (Bouchet, 2013). Menurut Glaubrecht et al. (2009) di antara semua anggota Genus Melanoides, M. tuberculata merupakan spesies yang mampu menyebar paling luas dengan sebaran alami dari Afrika Timur hingga India, Cina bagian selatan, sampai ke Filipina, bagian utara Taiwan hingga Asia Tenggara, Papua, New Guinea, Kepulauan Bismarck hingga Australia dan Kepulauan Pasifik. Bahkan dilaporkan pula keberadaannya dari Eropa, Amerika latin, Amerika 
Utara dan Selatan, Australia, serta New Zealand.

Kemampuan distribusinya yang tinggi membuat M. tuberculata dikatagorikan sebagai spesies invasif dan menjadi ancaman bagi kestabilan ekosistem perairan tawar dan keragaman komunitas fauna asli (Samadi et al., 1999; Facon et al., 2008). Tingginya kemampuan invasi keong ini selain disebabkan oleh kisaran toleransinya yang luas terhadap faktor-faktor abiotik habitat, juga karena sifat partenogenesis-nya yang memungkinkan individu tunggal mampu membentuk koloni baru. Sifat vivipar yang dimiliki oleh genus ini juga berpotensi menghasilkan juvenil dalam jumlah besar dan kemampuan bertahan hidup yang tinggi (Pointier, 1989; Pointier et al., 1998).

Wilayah Indonesia termasuk dalam distribusi alami M. tuberculata. Spesies ini telah dilaporkan keberadaannya sejak zaman Pliosin berdasarkan bukti fosil yang terdapat di daerah Bumiayu dan Trinil (Benthem-Jutting, 1937). Distribusi M. tuberculata di Indonesia cukup luas yaitu dilaporkan dari Sumatera, Jawa, Kalimantan, Sulawesi, Bali, Nusa Tenggara, serta Papua. Meskipun sebaran dan populasinya cukup tinggi di alam, namun di Indonesia spesies ini tidak digolongkan sebagai spesies alien yang merugikan.

Variasi cangkang $M$. tuberculata cukup tinggi sehingga menyulitkan dalam identifikasi apalagi karakter cangkangnya sangat mirip dengan Stenomelania punctata. S. punctata awalnya oleh beberapa ahli dianggap sebagai anggota dari genus Melanoides (sensu lato). Namun demikian spesies M. tuberculata dan beberapa spesies Stenomelania ternyata diketahui memiliki strategi reproduksi yang berbeda (Starmühlner, 1982; Bandel dan Riedel, 1998).

Penelitian tentang strategi reproduksi dan ontogeni pada keong Melanoides (sensu lato) termasuk $M$. tuberculata dan S. punctata, masih sangat kurang, sehingga dalam identifikasi sering ditemukan kesalahan. Oleh karena itu penelitian lebih mendalam tentang karakter-karakter morfologi, ontogeni dan strategi reproduksi pada kelompok Melanoides (sensu lato) perlu dilakukan agar dapat membedakan dengan pasti identitas spesies M. tuberculata dari S. punctata.

\section{BAHAN DAN CARA KERJA}

Spesimen yang digunakan adalah materi ilmiah koleksi Museum Zoologicum Bogoriense, Pusat Penelitian Biologi - LIPI, berupa awetan kering dan awetan basah. Spesimen yang dipakai berasal dari enam lokasi berbeda, masing-masing diambil 20 individu (Tabel 1).

Tabel 1. Spesimen Melanoides dan Stenomelania yang digunakan sebagai sampel penelitian (Melanoides and Stenomelania specimens used for research material)

\begin{tabular}{|c|c|c|c|c|c|}
\hline $\begin{array}{l}\text { Spesies } \\
\text { (Species) }\end{array}$ & No & $\begin{array}{l}\text { No Kata- } \\
\log (\text { Cata- } \\
\log \text { number })\end{array}$ & Lokasi (Location) & Tanggal (Date) & $\begin{array}{l}\text { Jenis } \\
\text { awetan } \\
\text { (Preser- } \\
\text { vation) }\end{array}$ \\
\hline \multirow{3}{*}{ M. tuberculata } & 1 & $\begin{array}{l}\text { MZB Gst. } \\
12.657\end{array}$ & $\begin{array}{l}\text { Kolam Kebun Raya Bogor, Jawa } \\
\text { Barat }\end{array}$ & Juli 2005 & Kering \\
\hline & 2 & $\begin{array}{c}\text { MZB Gst. } \\
18.969\end{array}$ & $\begin{array}{l}\text { Kali Pu, Ds. Wailebet, P. Batanta, } \\
\text { Dstr. Selat Sagawin, Kepulauan } \\
\text { Raja Ampat, Papua Barat }\end{array}$ & 1 Mei 2008 & Basah \\
\hline & 3 & $\begin{array}{l}\text { MZB Gst. } \\
16.226\end{array}$ & $\begin{array}{l}\text { Sungai Kel. Ulung, Kec.Kolaka, } \\
\text { Kab. Kolaka Utara, Sulawesi } \\
\text { Tenggara }\end{array}$ & Juli 2011 & Basah \\
\hline \multirow{3}{*}{ S. punctata } & 4 & $\begin{array}{c}\text { MZB Gst. } \\
17.554\end{array}$ & $\begin{array}{l}\text { Muara Sungai Lempenge, Dsn. } \\
\text { Lempenge, Ds. Rempeg, Kec. } \\
\text { Gangga, Kab. Lombok Utara }\end{array}$ & 28 April 2014 & Basah \\
\hline & 5 & $\begin{array}{l}\text { MZB Gst. } \\
15.851\end{array}$ & Taman Jaya, Banten & 1984 & Kering \\
\hline & 6 & $\begin{array}{c}\text { MZB Gst. } \\
13.899\end{array}$ & $\begin{array}{l}\text { Sungai Wairabiai, Ds. Warsamdin, } \\
\text { Pulau Waigeo, Distr. Teluk Ma- } \\
\text { yalibit, Kepulauan Raja Ampat, } \\
\text { Papua Barat }\end{array}$ & 3 Juni 2007 & Basah \\
\hline
\end{tabular}




\section{Analisis morfologi}

Morfologi spesimen diamati karakternya secara kuantitatif dan kualitatif. Data karakter kuantitatif diperoleh dari pengukuran pada dimensi cangkang berdasarkan Dechruksa et al. (2013), yaitu meliputi pengukuran tinggi cangkang (TC), lebar cangkang (LC), tinggi seluk tubuh (TST), tinggi apertur (TA), dan lebar apertur (LA). Pengukuran ini dilakukan dengan menggunakan kaliper digital dengan tingkat akurasi $0,01 \mathrm{~mm}$.

Karakter kualitatif diperoleh dengan melakukan pengamatan pada karakter jumlah seluk, warna cangkang, ornamen permukaan cangkang yang meliputi garis tumbuh aksial dan spiral, dan bentuk operkulum (Isnaningsih et al., 2017). Pengamatan terhadap ciri-ciri morfologi yang bersifat mikroskopis dilakukan di bawah mikroskop dengan perbesaran 10x untuk melihat karakter jumlah garis aksial dan spiral serta ornamen-ornamen cangkang. Selain karakter-karakter yang terlihat pada cangkang, dilakukan pula pengamatan terhadap tubuh lunak hewan yang meliputi pencandraan terhadap ciri-ciri pada head-foot dan mantel.

\section{Analisis embrio dan ontogeni}

Data ontogeni diperoleh dengan melakukan pembedahan subhaemocoelic brood pouch yang terletak di bagian anterior untuk mendapatkan embryonic shell (ES). Ekstraksi ES dilakukan mengikuti metode Dechruksa et al. (2013). Embryonic shell yang didapat lalu dipisahkan ke dalam beberapa kisaran ukuran mengikuti Isnaningsih et al. (2017), yaitu : (1) $\leq 1 \mathrm{~mm},(2) 1,1$ $-2 \mathrm{~mm}$, (3) $2,1-3 \mathrm{~mm}$, (4) $>3 \mathrm{~mm}$.

\section{HASIL}

THIARIDAE

Melanoides Olivier, 1804

Melanoides tuberculata (Müller, 1774)

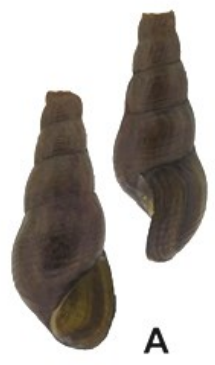

A

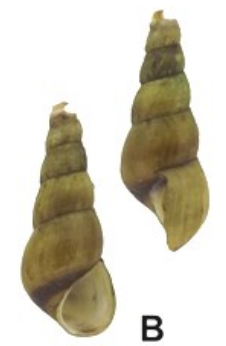

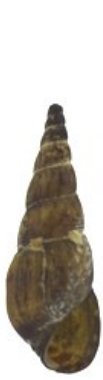
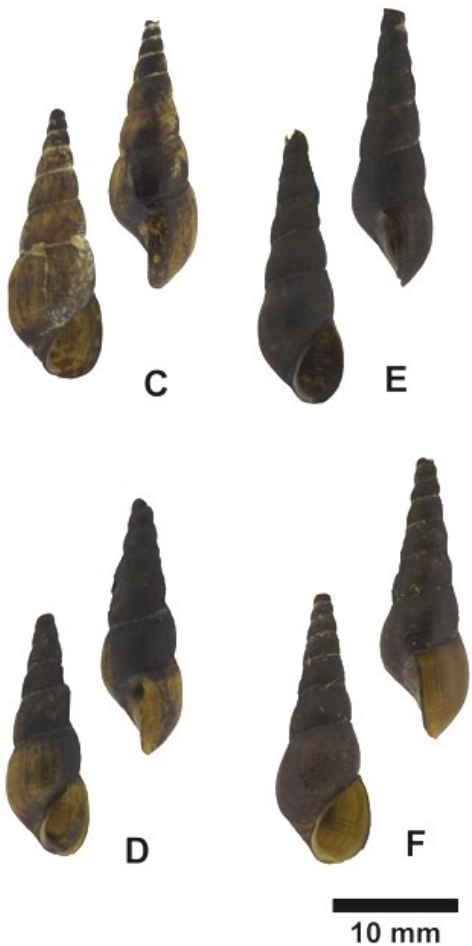

Gambar 1. Variasi morfologi intra-spesies pada cangkang M. tuberculata: (A-B) MZB Gst.12.657 Bogor, Jawa Barat; (C-D) MZB Gst.18.969 Batanta, Papua Barat; (E-F) MZB Gst.16.226 Kolaka, Sulawesi Tenggara (Foto: NR. Isnaningsih). (Intervariation morphology in M.tuberculata shell. (A-B) MZB Gst.12.657 Bogor, Jawa Barat; (C-D) MZB Gst.18.969 Batanta, Papua Barat; (E-F) MZB Gst.16.226 Kolaka, Sulawesi Tenggara (Photo: NR. Isnaningsih)). 


\section{Taksonomi dan Sistematika}

Spesies M. tuberculata dideskripsi pertama kali oleh Othon Friderico Müller pada tahun 1774 dengan type locality Coromandel, India. Selanjutnya Lamarck (1822) menyebut spesies ini dengan Melania truncatula. Beberapa ahli menyebutkan nama Melania tuberculata yang merujuk pada spesies yang sama (Mousson, 1848; Brot, 1874; Benthem-Jutting, 1932). Pada perkembangan berikutnya, terdapat lebih dari 25 nama yang merujuk pada Melanoides tuberculata. Revisi terakhir dilakukan oleh Benthem-Jutting (1956) yang memasukkan spesies tersebut sebagai anggota genus Melanoides Olivier,1808 sehingga menjadi Melanoides tuberculata.

\section{Deskripsi}

Nama jenis - Melanoides tuberculata

Nama asing - Red Rimmed Melania

Nama lokal - Sumpil (Jawa), Susuh Poleng (Sunda)

Cangkang - berukuran sedang (15,39-46,78 $\mathrm{mm}$ ), bentuk cangkang memanjang. Permukaan cangkang umumnya halus, garis tumbuh aksial tidak terpahat dengan jelas. Pada beberapa spesimen, garis tumbuh spiral terlihat samar terutama di bagian seluk tubuh. Permukaan cangkang berwarna kuning cerah hingga kuning kecoklatan, beberapa diantaranya juga berwarna kuning kehijauan. Terdapat titik (dots) atau berkas (flames) berwarna coklat yang tersusun irregular atau terdapat di bawah sutura pada tiap seluk. Pita (band) berwarna cokat juga seringkali terlihat pada bagian basal cangkang mengelilingi pusat cangkang. Puncak cangkang meruncing, kadangkadang terkikis. Terdiri dari 10-15 seluk. Menara cangkang sedang hingga tinggi. Seluk tubuh membulat dengan tinggi cangkang bervariasi antara 1,5 hingga hampir 3 kali lipat seluk tubuh. Sutura melekuk, dangkal. Mulut cangkang menyudut di bagian atas dan membulat di bagian bawah. Bentuk tersebut menciptakan variasi intra spesies pada mulut cangkang yaitu berbentuk oval atau membulat, tepi mulut cangkang tidak menerus dan apabila dilihat dari samping terlihat melekuk. Pusat cangkang tertutup (Gambar 1).

Operkulum - tipe paucispiral, inti operkulum terletak di bagian tepi bawah, delapan lingkaran operkulum terpahat di permukaan bagian luarnya.

Tubuh lunak - tubuh hewan terdiri dari 3,5-4,5 putaran, bagian kepala-kaki berwarna abu-abu atau hitam, mantel berwarna putih atau kekuningan dengan garis hitam di bagian tepinya. Tepi mantel serrated dan dilengkapi dengan sejumlah papila. Tubuh berwarna putih dan kecoklatan pada bagian posterior. Sepasang mata terletak di bagian dasar antena. Ctenidium panjangnya \pm 2 kali panjang osphradium-nya.

Embryonic shell - berukuran 0,1-5,9 mm atau mencapai tinggi 1-7 seluk. Cangkang tipis dan transparan. Pada awal terbentuknya, terlihat garis tumbuh aksial yang samar pada permukaan cangkang. Dua lingkaran garis tumbuh spiral juga terlihat samar pada masing-masing seluk. Namun seiring dengan pertambahan ukuran, garis tumbuh aksial dan spiral terlihat sangat jelas karena terpahat kuat pada semua seluk. Pada bagian tubuh di bawah periphery, hanya garis tumbuh spiral yang terlihat kuat. Berkas berwarna coklat tua sudah terlihat pada masing-masing seluk dan tersusun longitudinal. Protoconch atau seluk puncak dan seluk di bawah seluk puncak memiliki permukaan yang halus. Apabila dilihat dari atas, garis lingkaran luar seluk terlihat lurus.

Habitat - hidup pada perairan lentik maupun lotik, buatan maupun alami.

Distribusi - Berdasarkan koleksi MZB Sumatera: Kutacane, Toba, Lubuk Linggau, Lahat, Langkat, Ogan Komering Ilir, Jambi, Lampung. Jawa: Teluk Jakarta, Bogor, Sukabumi, Pangandaran, Ciburial, Ujung Genteng, Cibodas, Garut, Gombong, Ambarawa, Kebumen, Salatiga, Malang, Jember, Sumenep. Sulawesi: Bulukumba, Malili, Minahasa, Maros, Tominanga, Luwu, Tentena, Lindu, Matano, Gumbasa, Palu, Kolaka. Kalimantan: Mahakam, Balikpapan. Nusa Tenggara: Lombok, Sumbawa. Papua: Batanta. 

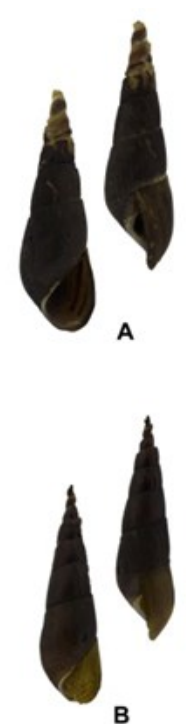
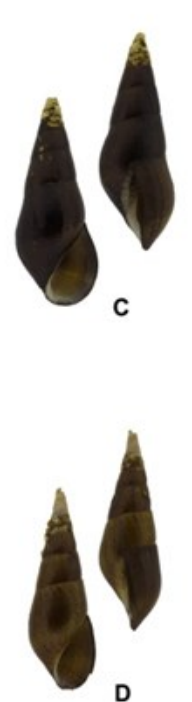
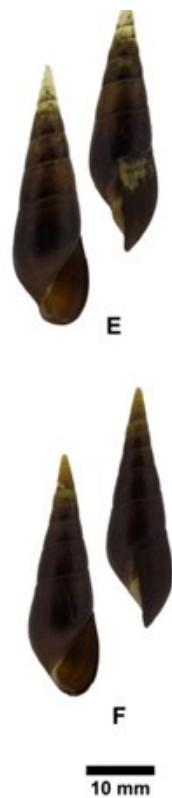

Gambar 2. Variasi morfologi intra-spesies pada cangkang S. punctata: (A-B) MZB Gst.17.554 Lombok, NTB; (C-D) MZB Gst.15.851 Banten, (E-F) MZB Gst.13.899 Waigeo, Papua Barat (Foto: NR. Isnaningsih). (Intervariation morphology in S. punctata shell: (A-B) MZB Gst.17.554 Lombok, NTB; (C-D) MZB Gst.15.851 Banten, (E-F) MZB Gst.13.899 Waigeo, Papua Barat. (Photo: NR. Isnaningsih)).

\section{Taksonomi dan sistematika}

Spesies ini dideskripsi pertama kali oleh Lamarck (1822) sebagai Melania punctata. Nama tersebut diikuti oleh Brot (1874). Sejumlah nama menjadi sinonim untuk menyebutkan spesies Stenomelania punctata antara lain Melania sobria (Reeve, 1859), Melania semiornata (Brot, 1874), Melania clavus (Rensch, 1934). Pada publikasi selanjutnya oleh Benthem-Jutting (1941), spesies ini dimasukkan sebagai anggota genus Thiara menjadi Thiara punctata dan kemudian direvisi menjadi Melanoides punctata (Benthem-Jutting, 1956). Pada tahun 1984, Starmühlner memasukkan spesies ini ke dalam sub-genus Stenomelania mengingat strategi reproduksinya yang berbeda dengan genus Melanoides (sensu stricto) yang lain. Klasifikasinya tersebut kemudian diikuti oleh Glaubrecht (1999).

\section{Deskripsi}

Nama spesies - Stenomelania punctata

Nama asing - n/a

Nama lokal - Sumpil (Jawa), Susuh Poleng (Sunda)

Cangkang - Cangkang tebal, berukuran sedang hingga besar $(24,30-46,78 \mathrm{~mm})$, bentuk memanjang. Permukaan cangkang halus, garis tumbuh aksial dan spiral tidak nyata terlihat, kecuali pada beberapa spesimen yang memperlihatkan adanya garis spiral pada seluk tubuh di bagian bawah periphery. Permukaan cangkang berwarna coklat hingga coklat kehitaman, umumnya warna semakin gelap ke arah puncak cangkang. Terdapat titik (dots) atau berkas (flames) berwarna coklat yang tersusun transversal dan tidak beraturan irregular dengan posisi di bawah sutura pada tiap seluk. Pada beberapa spesimen juga terlihat adanya berkas berwarna gelap yang tersusun memanjang (longitudinal) di bagian seluk tubuh. Puncak cangkang meruncing, kadang-kadang terkikis. Terdiri dari 16-18 seluk. Menara cangkang sedang hingga tinggi. Seluk tubuh lurus, tinggi cangkang mencapai 1,7 hingga 2,6 kali lipat seluk tubuh. Sutura melekuk, dangkal. Mulut cangkang ovalmenyempit, tepi mulut cangkang tidak menerus dan apabila dilihat dari samping terlihat lurus. Pusat cangkang tertutup (Gambar 2).

Operkulum - tipe paucispiral, inti Operkulum terletak di bagian tepi bawah, berkas-berkas lingkaran operkulum tidak terlihat secara jelas.

Tubuh - Tubuh lunak, terdiri dari empat putaran, bagian kepala-kaki hitam, abu-abu, bagian leher kuning atau jingga, mantel berwarna 
kekuningan dengan garis hitam di bagian tepinya. Tepi mantel serrated dan dilengkapi dengan sejumlah papila. Sepasang mata terletak di bagian dasar antena. Perbandingan Ctenidium: Osphradium adalah 4:3.

Embryonic shell - Dari 40 spesimen yang dibedah tidak satupun dijumpai adanya embryonic shell dalam subhaemocoelic brood pouch. Namun demikian pada beberapa spesimen terlihat adanya progeni tanpa cangkang berukuran kurang dari 0,1 mm dalam jumlah yang cukup banyak.

Habitat - dijumpai hidup pada muara-muara sungai yang berbatasan langsung dengan laut. Lebih menyukai dasar perairan yang berpasir atau kerikil kecil.

Distribusi - Berdasarkan koleksi MZB - Ujung Kulon, Banten (Jawa Barat), P. Panaitan, Maros (Sulawesi Selatan), Lombok, Flores, P. Buru, P. Obi, dan P. Waigeo.

\section{Variasi morfologi intra dan antar spesies}

Pengukuran terhadap karakter tinggi cangkang menunjukkan bahwa spesimen dari Bogor memiliki kisaran ukuran terkecil yaitu 15,39-26,66 mm diikuti berturut-turut dengan spesimen dari Kolaka (17,65-30,45 mm), Batanta (24,00-30,86 mm), Lombok $(24,30-46,78 \mathrm{~mm})$ dan Banten $(28,21-$ 43,25 mm). Sementara itu spesimen dari Pulau Waigeo mempunyai kisaran tinggi cangkang terbesar yaitu 34,40-46,37 mm (Gambar 3).

Perbedaan karakter morfologi yang memisahkan antara $M$. tuberculata dengan $S$. punctata adalah bentuk tepi seluk yang membulat pada $M$. tuberculata, sementara $S$. punctata memiliki bentuk tepi seluk yang rata. Karakter ini apabila diperhatikan akan membuat $M$. tuberculata memiliki garis tepi cangkang yang berlekuk-lekuk dan $S$. punctata terlihat memiliki garis tepi cangkang yang rata.

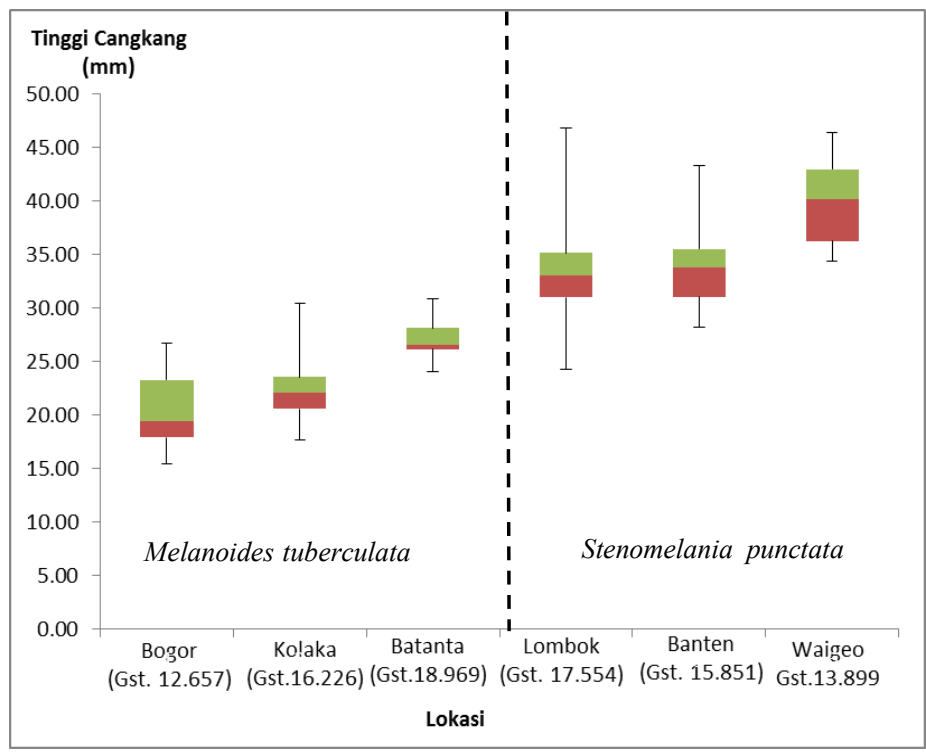

Gambar 3. Tinggi cangkang M. tuberculata dan S.punctata. (Shell height of M. tuberculata and S.punctata).

Beberapa karakter morfologi cangkang seperti warna cangkang, garis tumbuh, dan bentuk mulut cangkang tidak menunjukkan perbedaan yang nyata antara spesies $M$. tuberculata dengan $S$. punctata. Keduanya memiliki cangkang berwarna kuning, kecoklatan, hingga coklat kehitaman. Spesimen M. tuberculata dari Bogor berwana kuning kehijauan, dari Waigeo dan Kolaka berwarna coklat muda di bagian seluk tubuh dan coklat tua di bagian sulurnya, sedangkan $S$. punctata berwarna coklat hingga coklat kehitaman. Baik $M$. tuberculata maupun $S$. punctata dari semua lokasi umumnya memiliki permukaan cangkang halus karena garis tumbuh aksial dan spiral tidak tergurat secara jelas. Namun demikian pada sejumlah spesimen yaitu M. tuberculata dari Bogor dan Kolaka serta S. punctata dari Banten memiliki garis tumbuh spiral yang jelas terlihat pada bagian bawah cangkang di sekitar umbilikus.

\section{Studi ontogeni}

Pembedahan hanya dilakukan pada spesimenspesimen dari empat lokasi (awetan basah) yaitu $M$. tuberculata dari Batanta dan Kolaka dan 
S. punctata dari Lombok dan Waigeo. Dari 20 spesimen $M$. tuberculata dari Batanta, 14 diantaranya menyimpan ES sedangkan 15 individu M. tuberculata dari Kolaka menyimpan ES (Gambar 4A-B). Hasil pembedahan terhadap $S$. punctata dari Waigeo dan Lombok tidak dijumpai
ES dalam subhaemocelic brood pouch (Gambar 4C). Namun demikian pada beberapa spesimen terlihat adanya progeni pada stadia tanpa cangkang berukuran kurang dari $1 \mathrm{~mm}$ dalam jumlah yang banyak (Gambar 4D).
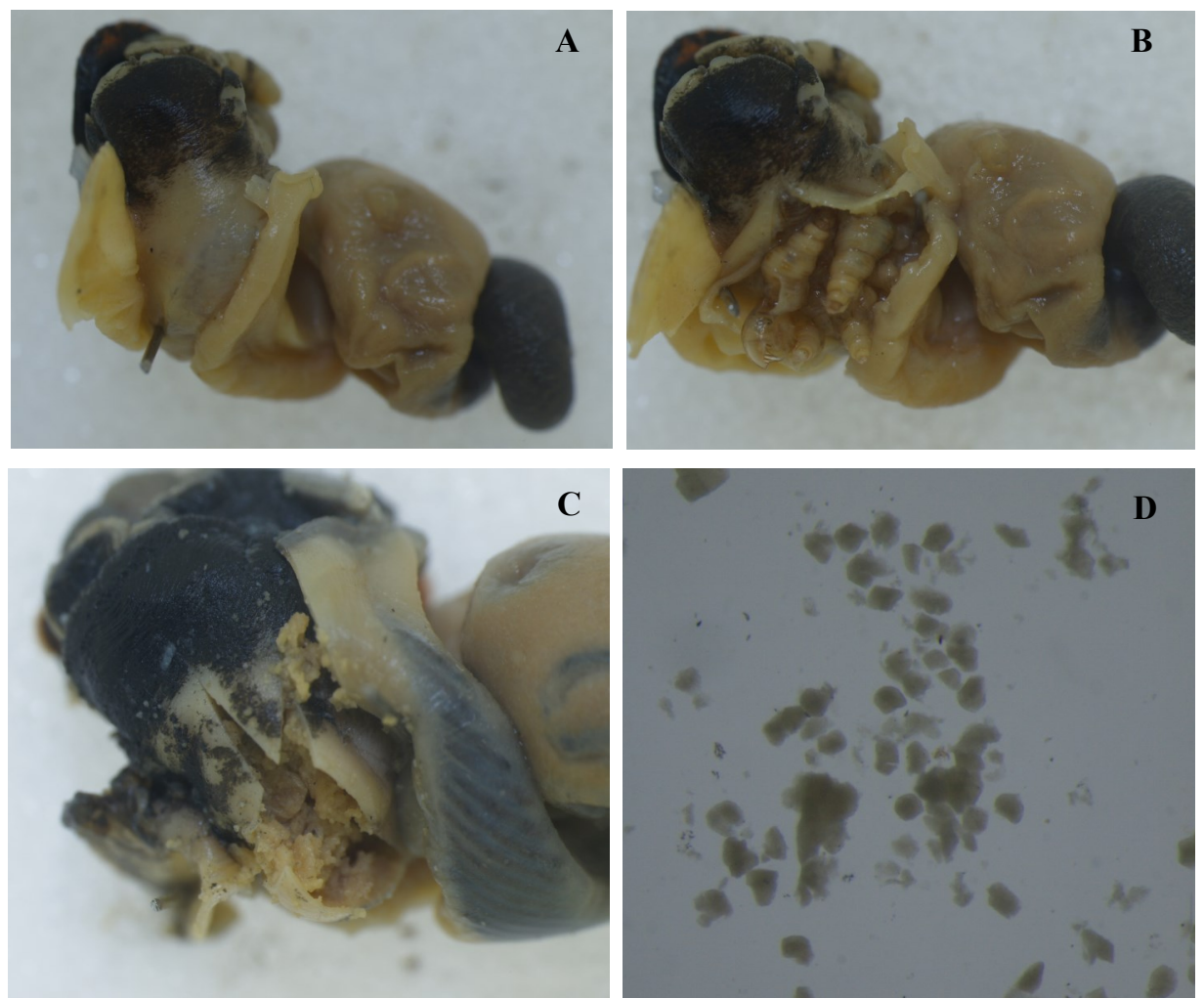

Gambar 4. Subhaemocoelic brood pouch M. tuberculata (A-B) dan S. punctata. (C-D) : (A) Tampilan eksternal bagian head-foot, (B) Setelah dibedah dan berisi sejumlah ES, (C) Subhaemocoelic brood pouch yang mengandung unshell embryo, (D) unshell embryo yang berkembang menjadi free swimming veliger. (Foto. NR. Isnaningsih). (Subhaemocoelic brood pouch of M. tuberculata (A-B) and S.punctata. (C-D): (A) External view of head-foot, (B) After dissecting and containing a number of ES, (C) Subhaemocoelic brood pouch containing unshell embryo, (D) Unshell embryo develop as free swimming veliger (Photo. NR. Isnaningsih)).

Pengamatan jumlah ES pada $M$. tuberculata menunjukkan perbedaan yang signifikan antara $M$. tuberculata dari Kolaka dan Batanta. Satu individu dewasa $M$. tuberculata dari Kolaka mampu menyimpan anakan dengan kisaran antara 1-66 ES, sedangkan satu individu dewasa $M$. Tuberculata dari Batanta hanya menghasilkan anakan sebanyak 1-6 ES saja (Gambar 5A).

Embryonic shell yang tersimpan dalam tubuh induknya di saluran subhaemocoelic broodpouch, dijumpai dalam berbagai ukuran yaitu $0,1-5,9 \mathrm{~mm}$.
Hal ini menandakan adanya perkembangan dalam tubuh induk (Gambar 6). Pada perkembangan awal, bentuk ES masih sederhana dan cangkang hanya tersusun atas 2-3 seluk saja. Pada fase ini, ES berukuran kurang dari $1 \mathrm{~mm}$ dan terus berkembang seiring dengan bertambahnya jumlah seluk. Garis tumbuh aksial dan spiral pada ES yang berukuran 2 $-4 \mathrm{~mm}$ terlihat jelas. 

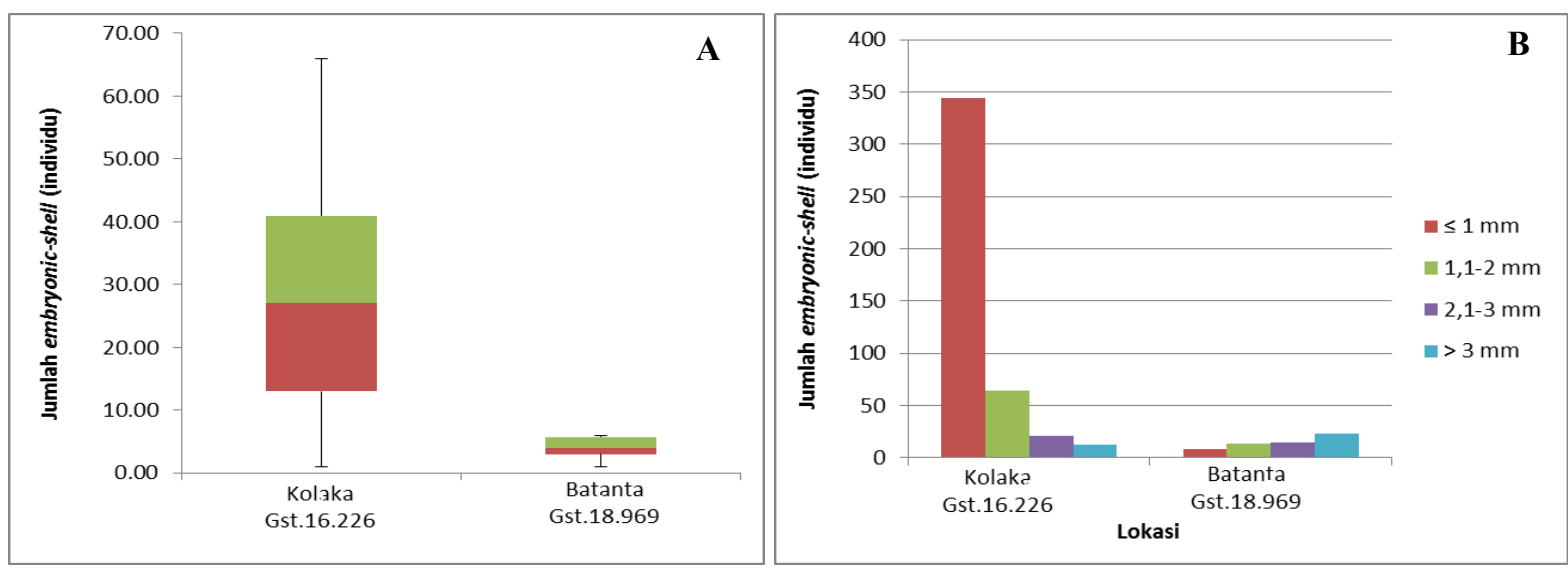

Gambar 5. Data ES M. tuberculata dari Kolaka dan Batanta: (A). Jumlah ES. (B) Komposisi ES $M$. tuberculata dalam 4 kisaran ukuran pertumbuhan. (Data of M. Tuberculata ES from Kolaka and Batanta: (A) Number of ES. (B) Composition of M. tuberculata ES found in four different ontogenetic stages).

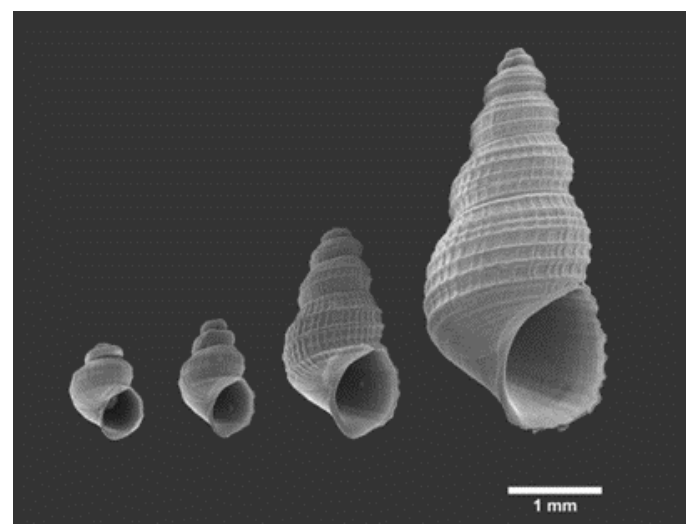

Gambar 6. Perkembangan bentuk ES pada M. tuberculata dalam subhaemocoelic broodpouch individu dewasa (Foto: NR. Isnaningsih). (ES development of M. tuberculata in subhaemocoelic broodpouch of adult (Photo: NR. Isnaningsih)).

Pada M. tuberculata dari Kolaka, sebanyak 441 ES tersimpan dalam subhaemocoelic brood pouch 15 individu dewasa dengan rincian 344 ES berukuran kurang dari $1 \mathrm{~mm}, 64$ ES berukuran 1,12,0 $\mathrm{mm}, 21 \mathrm{ES}$ berukuran 2,1-3,0 $\mathrm{mm}$ dan $21 \mathrm{ES}$ berukuran lebih dari $3 \mathrm{~mm}$. Adapun spesies $M$. tuberculata dari Batanta memiliki kisaran ukuran antara $0,53-5,95 \mathrm{~mm}$. Komposisi fase ES pada $M$. tuberculata dari Batanta dan Kolaka ternyata menunjukkan tren yang berbeda. Jumlah ES terbanyak M. tuberculata dari Batanta justru yang berukuran lebih dari $3 \mathrm{~mm}$, yaitu sebanyak $23 \mathrm{ES}$. Adapun sebanyak 13 ES dijumpai berukuran kurang dari $1 \mathrm{~mm}, 13$ ES berukuran $1,1-2,0 \mathrm{~mm}$ dan 14 ES berukuran 2,1-3,0 mm (Gambar 5B).

\section{PEMBAHASAN}

Variasi morfologi intra dan antar-spesies

Berdasarkan pengamatan yang dilakukan pada $M$. tuberculata dan S. punctata masing-masing dari tiga lokasi yang berbeda, terlihat bahwa terdapat sejumlah variasi pada karakter-karakter morfologi cangkang. Variasi intra-spesies pada $M$. tuberculata dari Bogor, Kolaka, dan Batanta terlihat pada karakter tinggi cangkang, warna cangkang, ada tidaknya ornamen cangkang (berkas, titik, pita), serta kondisi garis tumbuh yang terlihat (Gambar 1). Karakter-karakter tersebut juga bervariasi pada spesies S. punctata dari Lombok, Banten, dan Waigeo (Gambar 2).

Dechruksa et al. (2013) yang meneliti populasi M. tuberculata di Thailand menjumpai adanya 10 
variasi morfologi. Variasi tersebut terlihat pada dimensi cangkang, jumlah garis tumbuh, jumlah dan bentuk seluk, bentuk sutura serta bentuk apertura. Yousif et al. (2009) juga melaporkan adanya lima variasi morfologi pada spesies $M$. tuberculata dari delta Sungai Nil dan Sinai, Mesir yakni pada karakter warna cangkang, bentuk seluk tubuh, dan dimensi cangkang. Penelitian terhadap $M$. tuberculata dari Timur-tengah dan Afrika menunjukkan terdapat sekitar 16 variasi morfologi yang berbeda terutama pada karakter warna dan ornamentasi cangkang (Samadi et al., 1999). Banyaknya variasi-variasi morfologi pada suatu populasi lebih lanjut akan berpengaruh hingga ke tingkat molekuler (Facon et al., 2008).

Variasi antar spesies dalam hal ini antara $M$. tuberculata dan $S$. punctata digunakan sebagai dasar dalam pemisahan penentuan identitasnya. Antara keduanya memiliki ciri-ciri yang sama pada karakter bentuk cangkang yang memanjang (turreted). Karakter warna dan ornamen cangkang yaitu keberadaan dan letak berkas/titik/pita pada permukaan cangkang, ternyata tidak dapat dijadikan sebagai karakter yang memisahkan $M$. tuberculata dengan S. punctata. Karakter yang dapat membedakan antara keduanya adalah garis tepi (outline) cangkang dan bentuk seluk. M. tuberculata memiliki garis tepi berlekuk-lekuk dengan bentuk seluk yang membulat, sementara garis tepi dan bentuk seluk $S$. punctata adalah rata. Namun demikian berdasarkan Glaubrecht et al. (2009) bentuk seluk dan tepi seluk yang rata bukan merupakan ciri spesifik dari genus Stenomelania karena spesies $S$. denisoniensis dan $S$. aspiran dari Australia memiliki bentuk seluk yang concave seperti M. tuberculata.

Melanoides tuberculata dan S. punctata dapat dijumpai pada habitat yang sama. Keduanya lebih menyukai hidup di air yang tenang atau menggenang dibandingkan dengan perairan yang berarus deras. Umumnya $M$. tuberculata dan $S$. punctata dijumpai hidup menempel pada akar atau batang rerumputan di tepi sungai atau tanaman air lainnya. Kedua spesies tersebut juga biasa membenamkan diri pada substrat perairan yang berlumpur. $M$. tuberculata lebih menyukai hidup di sungai yang tawar, sementara $S$. punctata umumnya terdapat pada muara-muara sungai yang masih dipengaruhi oleh salinitas laut akibat pasang surut (Starmühlner, 1982; Bandel dan Riedel, 1998).

\section{Studi ontogeni}

Studi ontogeni melalui pembedahan yang dilakukan pada spesimen $M$. tuberculata dan $S$. punctata menunjukkan adanya fase ontogeni yang berbeda. Pada $M$. tuberculata dijumpai adanya 1-66 ES dalam tubuh 1 induk. Sementara itu, pada $S$. punctata sama sekali tidak dijumpai adanya ES. Namun demikian bentukan progeni tanpa cangkang terlihat pada beberapa subhaemocoelic brood pouch jenis $S$. punctata. Berbeda dengan pengamatan berdasarkan karakter morfologi, hasil pembedahan pada organ reproduksi ini secara jelas memisahkan antara kedua spesies tersebut. Hal ini sejalan dengan yang dijelaskan pada sejumlah penelitian sebelumnya bahwa Genus Melanoides memiliki strategi reproduksi euvivipar yaitu melahirkan anakan namun menyimpan (memelihara) anakan nya tersebut terlebih dahulu pada organ subhaemocoelic brood pouch sebelum melepaskan ke habitatnya. Sementara itu S. punctata bereproduksi dengan jalan melahirkan anaknya, menyimpan dalam subhaemocoelic brood pouch dan melepaskan ke alam dalam bentuk larva bebas (free swimming veliger) yang kemudian menjadi dewasa di habitat perairan (Bandel dan Riedel, 1998; Albrecht dan Glaubrecht, 2006).

\section{KESIMPULAN}

Variasi intra spesies Melanoides tuberculata dan Stenomelania punctata dari lokasi yang berbeda, terlihat pada karakter warna cangkang, ornamen cangkang (ada tidaknya dan posisi berkas dan pita), serta garis tumbuh. Variasi antar spesies $M$. tuberculata dan $S$. punctata yang dapat digunakan untuk membedakan keduanya yaitu karakter bentuk sutura dan garis tepi cangkang. Strategi reproduksi dan ontogeni antara $M$. tuberculata dan $S$. punctata juga menunjukkan perbedaan. $M$. tuberculata bereproduksi secara euvivipar dengan menyimpan embryonic shell pada organ subhaemocoelic brood pouch. Kemampuan reproduksi $M$. tuberculata berbeda antara populasi dari Kolaka dengan Batanta. Satu individu Melanoides tuberculata dari Kolaka dapat menyimpan 1-66 embryonic shell sedangkan dari Batanta diketahui hanya menyimpan 1-6 embryonic shell. Embryonic shell dijumpai berada dalam berbagai fase ukuran yang berkisar antara 0,12-5,95 $\mathrm{mm}$. Adapun pada $S$. punctata tidak dijumpai adanya embryonic shell namun terlihat adanya bentukan unshell embrio. S. punctata bereproduksi secara ovovivipar dengan cara melepaskan free swimming veliger 


\section{UCAPAN TERIMA KASIH}

Penulis mengucapkan terima kasih kepada saudari Kartika Dewi yang telah melakukan pengambilan foto SEM. Ucapan terima kasih juga tertuju untuk reviewer yang telah menelaah naskah ini. Para penulis mendeklarasikan bahwa Nur Rohmatin Isnaningsih dan Ristiyanti M. Marwoto adalah kontributor utama yang bertanggung jawab terhadap kegiatan penelitian dan penulisan. Alfiah, Riena Prihandini, dan Pramono H. Santoso merupakan kontributor anggota yang bertanggung jawab dalam penyiapan spesimen dan data penelitian.

\section{DAFTAR PUSTAKA}

Albrecht, C. and Glaubrecht, M., 2006. Brood care among Basommatophorans: A unique reproductive strategy in the freshwater limpet snail Protancylus (Heterobranchia: Protancylidae), endemic to ancient lakes on Sulawesi, Indonesia Acta Zoologica, 87, pp. 49-58.

Bandel, K. and Riedel, F., 1998. Ecological zonation of gastropods in the Matutinao River (Cebu, Philippines), with focus on their life cycles. Annales de Limnologie, 34 (2), pp. 171-191.

Bandel, K., Glaubrecht, M. and Riedel, F., 1997. On the ontogeny, anatomy, and ecology of the tropical freshwater gastropod Stenomelania (Cerithioidea, Thiaridae). Limnologia, 27, pp. 238-250.

Benthem-Jutting, W.S.S.van., 1932. On prehistoric shells from Sampoeng cave (Central Java). Treubia, 14, pp. 103-108.

Benthem-Jutting, W.S.S.van., 1937. Non marine Mollusca from fossil horizon in Java with special reference to the Trinil fauna. Zoologische Mededeelingen, 20,98 pp.

Benthem-Jutting, W.S.S.van., 1941. On a collections of nonmarine Mollusca from Talaud islands and from Morotai (Moluccas). Treubia, 18, pp. 1-27.

Benthem- jutting, W. S. S. van., 1956. Systematic studies on the non-marine Mollusca of the Indo-Australian archipelago. V. Critical revision of the Javanese freshwater gastropods. Treubia, 23, pp. 259-477.

Bouchet, P., 2013. Melanoides Olivier, 1804. In: Mollusca Base. Accessed through: World Register of Marine Species at http://www.marinespecies.org/aphia.php? $\mathrm{p}=$ taxdetails\&id $=224571$ on $2016-10-28$

Brot, A., 1874. Die melaniaceen (Melanidae) in Abbildungen nach der Natur mit Beschreibungen. In: H. C. Küster, ed. Systematisches Conchylien-Cabinet von Martini und Chemnitz, 1(24): 488 pp. 49 pls. Nurnberg, Bauer \& Raspe.

Dechruksa, W., Krailas, D. and Glaubrecht, M., 2013. Evaluating the status and identity of “Melania' jugicostis Hanley \& Theobald, 1876-an enigmatic thiarid gastropod in Thailand (Caenogastropoda, Cerithioidea). Zoosystematic and Evolution, 89(2), 293-310.

Djajasasmita, M., 1999. Keong dan Kerang Sawah. Seri Panduan Lapangan. Puslitbang Biologi-LIPI. Bogor. 57 hal.

Facon, B., Pointier, J., Jarne, P., Sarda, V. and Davis, P., 2008. High genetic variance in life history strategies within invasive population by way of multiple introductions. Current Biology, 18. pp. 363-367.

Glaubrecht, M., 1999. Systematics and the evolution of viviparity in tropical freshwater gastropods (Cerithioidea: Thiaridae sensu lato): An overview. Courier ForschungsInstitut Senckenberg, 215, pp. 91-96.

Glaubrecht, M., Brinkmann, N. and Poppe, J., 2009. Diversity and disparity "down under": Systematics, biogeography and reproductive modes of the 'marsupial' freshwater Thiaridae (Caenogastropoda, Cerithioidea) in Australia. Zoosystematic and Evolution, 85(2), pp. 199-275.

Isnaningsih, N.R., Basukriadi, A. and Marwoto, R.M., 2017. The morphology and ontogenetic of Tarebia granifera (lamarck, 1822) from Indonesia (Gastropoda: Cerithioidea: Thiaridae). Treubia, 44, pp. 1-14.

Lamarck, J.B.P.A. de M. de., 1822. Histoire Naturelle des Animaux sans vertèbres. Tome sixième, 2 me partie. Paris: $232 \mathrm{pp}$.

Mousson, A., 1848. Die Land und Süsswasser Mollusken von Java. Durck und Verlag von Friedrich Schulthess. Zürich.1-126, pls 1-22.

Pointier, J.P., Guyard, A and Mosser, A., 1989. Biological control of Biomphalaria glabrata and B. straminea by the competitor snail Thiara tuberculata in a transmission site of schistosomiasis in Martinique, French West Indies. Annals of Tropical Medicine and Parasitology, 83, pp. 263-269.

Pointier, J.P., Samadi, S., Jarne, P. and Delay, B., 1998. Introduction and spread of Thiara granifera (Lamarck, 1822 ) in Martinique, French West Indies. Biodiversity and Conservation, 7, pp. 1277-1290.

Rensch, B., 1934. Suswassermollusken der deutschen limnologischen Sunda Expedition. Archiv für Hydrobiologie, Suppl. 8, pp. 203-254.

Revee, L.A., 1859. Conchologica iconica: Illustrations of the shells of molluscous animals. Vol. 12. Revee Brothers, London, $1114 \mathrm{pp}$.

Samadi, S., Mavarez, J., Pointier, J., Delay, B. and Jarne, P., 1999. Microsatellite and morphological analysis of population structure in the parthenogenetic freshwater snail Melanoides tuberculata: Insights into the creation of clonal variability. Molecular Ecology, 8, pp. 1141-1153.

Starmühlner, F. 1982. Occurence, distribution and geographical range of the freshwater-gastropods of the Andaman Islands. Malacologia, 22 (1-2), pp. 455-462.

Yousif, F., Ibrahim, A. and Sleem, S., 2009. Morphological and Genetic Analyses of Melanoides tuberculata Populations in Egypt. Global Journal of Molecular Sciences, 4(2). Pp. 112-117. 